\title{
Pengembangan Bahan Ajar Fisika Berbasis Kearifan Lokal Anyaman Nyiru untuk Meningkatkan Pemahaman Konsep Siswa
}

\author{
Foni S. Sae ${ }^{1, *)}$, Vivi E.R. Husin ${ }^{2}$, Ruth N.K. Mellu ${ }^{3}$ \\ Sekolah Tinggi Keguruan dan Ilmu Pendidikan Soe, Soe, Indonesia \\ fonisaefisika@gmail.com ${ }^{1}$, vivielvi02@gmail.com ${ }^{2}$, ruthmellu87@gmail.com3 \\ ${ }^{*}$ Corresponding author
}

\section{Kata Kunci:}

Bahan Ajar Fisika; Kearifan

Lokal; Anyaman Nyiru;

Pemahaman Konsep

\begin{abstract}
ABSTRAK
Penelitian ini bertujuan untuk menghasilkan bahan ajar fisika berbasis kearifan lokal anyaman Nyiru untuk meningkatkan pemahaman konsep siswa. Populasi dan sampel dalam penelitian ini adalah siswa kelas X SMA Kristen 1 SoE pada materi Hukum Newton. Penelitian ini menggunakan metode Research and Development $(R \& D)$. Tahapan penelitian ini menggunakan beberapa langkah-langkah, yaitu (1) potensi dan masalah; (2) pengumpulan informasi; (3) desain produk; (4) validasi produk; (5) perbaikan produk; (6) uji coba lapangan (skala kecil). Instrumen yang digunakan dalam penelitian ini adalah soal tes, lembar angket validasi, dan angket respon siswa. Teknik pengumpulan data menggunakan teknik tes dan teknik angket. Teknik analisis yang digunakan adalah teknik analisis deskriptif kuantitatif dengan metode presentase. Analisis deskriptif digunakan untuk mendeskripsikan hasil pengembangan dan analisis kuantitatif digunakan untuk menganalisis hasil validasi dan respon siswa serta uji Normalized gain untuk melihat peningkatan pemahaman konsep siswa. Hasil penelitian menunjukkan bahwa hasil validasi bahan ajar oleh 4 orang validator dengan rata-rata persentase media bahan ajar adalah $79 \%$ dengan kategori valid dan rata-rata persentase materi adalah $82 \%$ dengan kategori valid. Nilai $N$-gain terhadap pemahaman konsep siswa diperoleh nilai rata-rata sebesar 0,82 dengan kriteria tinggi dan data terhadap respon siswa diperoleh nilai rata-rata sebesar 74,86\% dengan kriteria Baik. Hal ini dapat disimpulkan bahwa bahan ajar berbasis kearifan lokal anyaman Nyiru yang dikembangkan valid sehingga dapat dijadikan sebagai salah satu sumber belajar dalam kegiatan pembelajaran fisika di sekolah.
\end{abstract}

\section{PENDAHULUAN}

Bahan ajar merupakan komponen penting dalam proses pembelajaran karena bahan ajar dijadikan sebagai sumber belajar bagi siswa dan guru dalam memperoleh informasi. Kegiatan pembelajaran saat ini memerlukan media/sumber belajar yang dapat diciptakan oleh guru agar dapat dipelajari, dicermati dan dikuasai oleh peserta didik dalam mempelajarinya (Tanjung \& Fahmi, 2015). Menurut Nurrahmi (2018), guru membutuhkan kemampuan menciptakan suasana lingkungan belajar yang bermakna dan 
dapat mengembangkan materi pelajaran yang disesuaikan dengan karakteristik ataupun potensi daerah tempat tinggal peserta didik. Materi pelajaran yang disesuaikan dengan keadaaan sekitar tempat tinggal akan memudahkan peserta didik dalam memahami materi pelajaran. Namun, hal tersebut masih jauh dari harapan karena selama ini yang terjadi di sekolah masih bersifat meneruskan informasi dari guru ke peserta didik, padahal pembelajaran dikatakan berhasil jika ada perubahan pengetahuan dan pemahaman peserta didik terhadap materi yang dipelajari (Satriawan \& Rosmiati, 2016). Untuk meningkatkan pemahaman belajar bagi peserta didik maka diperlukan strategi yang tepat dalam kegaiatn KBM khususnya dalam pembelajaran fisika (Rahayu, Sutikno, \& Masturi, 2015).

Fisika merupakan salah satu cabang IPA yang bertujuan mempelajari dan menganalisis gejala atau proses alam serta sifat penerapannya (Rahayu, Sutikno, \& Masturi, 2015). Fisika juga membutuhkan sarana dan prasarana dalam pembelajaran fisika akan lebih bermakna apabila terdapat kesinambungan antara materi mata pelajaran dengan aktivitas kehidupan sehari-hari di lingkungan tempat tinggal peserta didik yang digunakan sebagai sarana belajar. Menurut Bakhtiar (2016), Ilmu Pengetahuan Alam (IPA) merupakan konsep pembelajaran mengenai gejala alam yang mempunyai hubungan dengan kehidupan manusia. Suasana lingkungan belajar yang kondusif untuk proses pembelajaran IPA sangat beragam, tetapi dalam sudut pandang konteks, peserta didik akan lebih tepat jika mengoptimalkan kearifan lokal yang ada di lingkungan sekitar peserta didik. Trianto (2011) menjelaskan bahwa dengan menerapkan prinsip pembelajaran kontekstual diharapkan pembelajaran akan lebih bermakna bagi peserta didik, karena peserta didik mengalami sendiri bukan hanya mentransfer pengetahuan pendidik ke peserta didik. Menurut Oktaviani, Gunawan, dan Sutrio (2017), pembelajaran adalah proses interaksi antara peesrta didik dengan pendidik dan sumber belajar pada lingkungan belajar. Dengan demikian bahan ajar yang dikembangkan harus dicantumkan fenomenafenomena sudah dialami oleh siswa dalam lingkungan/kesehariannya sehingga memudahkan siswa dalam menyerap materi pembelajaran.

Berdasarkan hasil observasi yang dilakukan di SMA Kristen 1 SoE ditemukan bahwa pelaksanaan pembelajaran di dalam kelas belum sepenuhmya menghubungkan dengan kehidupan nyata peserta didik dalam hal ini kearifan lokal yang ada di tempat tinggal peserta didik sehingga aktivitas belajar peserta didik dalam mata pelajaran fisika rendah padahal ketersedian bahan ajar akan membantu guru dalam mencapai tujuan pembelajaran. Oleh karena itu, sangat penting bagi guru dalam mengembangkan bahan ajar yang sesuai dengan kebutuhan peserta didik. Dengan mengintegrasikan kearifan lokal pada bahan ajar fisika diharapkan dapat mempermudah peserta didik dalam memahami dan mempelajari pelajaran fisika (Kuswandari, Sunarno, \& Supurwoko, 2013). Melalui bahan ajar fisika berbasis kearifan lokal ini siswa dapat belajar lebih banyak, meningkatkan keterampilan memecahkan soal melalui latihan, menilai sendiri hasil pekerjaan yang telah dilakukan. Menurut Satriawan dan Rosmiati (2016), salah satu pendukung pembelajaran yang perlu dikembangkan saat ini untuk melengkapi sarana/prasarana yang ada adalah ketersediaan bahan ajar yang memadai. Dengan adanya bahan ajar yang memadai, peserta didik dapat belajar dan mendiskusikan materi ajar sebelum pembelajaran dimulai. Walaupun ketersediaan bahan ajar fisika saat ini memang sudah banyak, akan tetapi kebanyakan bahan ajar fisika yang ada masih kurang dapat dicerna oleh peserta didik khususnya di sekolah-sekolah yang letaknya di luar kota atau pinggiran kota (Kuswandari, Sunarno, \& Supurwoko, 2013). Hal ini karena gaya bahasa yang terlalu rumit, permasalahan yang diangkat tidak pernah dialami atau diketahui oleh peserta didik, gambar-gambar yang ditunjukkan kurang jelas dan cenderung masih asing untuk dikonsumsi oleh peserta didik.

Menurut Satriawan dan Rosmiati (2016), bahan ajar fisika yang berbasis kontekstual, dengan mengintegrasikan kearifan lokal diharapkan akan mempermudahkan peserta didik dalam memahami dan menerima pelajaran fisika. Selain itu, peserta didik dapat mengambil pelajaran dari fenomena fisika yang dituangkan dalam bahan ajar yang sesuai dengan kearifan lokal, sehingga pemahaman konsep siswa menjadi lebih baik. Menurut Albab (2014), kualitas modul fisika berbasis kearifan lokal pada materi Hukum Newton dapat menunjukkan kategori sangat baik dan penilaian respon siswa pada uji coba lapangan skala besar menunjukkan kategori setuju. Husin, Wiyanto, dan Teguh (2018) menyatakan bahwa integrasi kearifan lokal rumah Umekbubu dalam bahan ajar dapat meningkatkan 
motivasi dan hasil belajar siswa. Pengintegrasian kearifan lokal pada pembelajaran fisika tentunya akan membantu pemahaman konsep fisika siswa. Menurut Satriawan dan Rosmiati (2016), pemahaman konsep dapat diartikan sebagai kemampuan siswa dalam memahami makna secara ilmiah, baik konsep secara teori maupun penerapannya dalam kehidupan sehari-hari. Pemahaman konsep merupakan bagian dari hasil dalam komponen pembelajaran. Dengan demikian pemahaman konsep merupakan bagian dari hasil belajar pada ranah kognitif. Sanjaya (2009) menyatakan bahwa ada beberapa indikator pemahaman konsep diantaranya: menafsirkan, mencontohkan, mengklasifikasikan, merangkum, menyimpulkan, membandingkan, menjelaskan. Oleh karena itu, penelitian ini bertujuan untuk menghasilkan bahan ajar fisika berbasis kearifan lokal anyaman Nyiru untuk meningkatkan pemahaman konsep siswa.

\section{METODE PENELITIAN}

Metode yang digunakan dalam penelitian ini adalah metode penelitian dan pengembangan Research and Development (Borg \& Gall, 1989) yang dimodifikasi menjadi enam langkah penting, yaitu: (1) potensi dan masalah, (2) pengumpulan informasi, (3) desain produk berbasis kearifan lokal, (4) validasi desain, (5) revisi produk, dan (6) uji coba produk (skala kecil) untuk menghemat waktu dan biaya penelitian. Populasi dan sampel yang digunakan adalah siswa kelas X SMA Kristen 1 Soe. Instrumen yang digunakan untuk mengumpulkan data pada penelitian ini ada 3 jenis, yaitu soal tes, lembar angket validasi, dan lembar angket respon siswa. Lembar validasi digunakan sebagai penilaian validitas bahan ajar yang dikembangkan yang dinilai oleh empat validator. Angket respon siswa ini digunakan untuk mengukur serta mengetahui kepraktisan dari bahan ajar fisika yang dikembangkan yang diisi oleh siswa setelah proses pembelajaran selesai dilaksanakan. Tes kognitif pemahaman konsep siswa berupa pretest dan posttest untuk mengukur efektifitas penggunaan bahan ajar yang dikembangkan dan pemahaman konsep fisika. Teknik analisis data yang digunakan pada penelitian dan pengembangan ini adalah teknik analisis kuantitatif dengan metode presentase dan uji $\mathrm{N}$-Gain untuk melihat peningkatan pemahaman konsep siswa sebelum dan sesudah pembelajaran menggunakan bahan ajar fisika berbasis kearifan lokal dan diakhiri dengan kesimpulan dan saran dengan cara pretest-posttest normalized gain (Sundayana, 2015). Analisis deskriptif digunakan untuk mendeskripsikan hasil pengembangan dan analisis kuantitatif digunakan untuk menganalisis hasil validasi dan respon siswa.

\section{HASIL DAN PEMBAHASAN}

\section{Potensi dan masalah}

Hasil observasi yang dilakukan di sekolah media pembelajaran seperti buku cetak Lembar Kerja Siswa (LKS), dan bahan ajar konvensional tetapi materi dan gambar-gambar dalam buku cetak belum sepenuhnya berbasis kontekstual atau belum nyata dalam kehidupan sehari-hari, sehingga saat belajar siswa merasa bosan dan rasa keingin tahuan siswa berkurang terhadap materi fisika. Faktor yang menyebabkan rendahnya pemahaman konsep siswa, yaitu pembelajaran fisika yang dijalankan oleh guru selama ini masih memisahkan pengetahuan formal fisika siswa dengan pengalaman sehari-hari siswa.

\section{Pengumpulan Informasi}

Berdasarkan observasi yang didapat dari guru bahwa buku ajar khusus dalam menyampaikan materi yang berkaitan tentang kearifan lokal tidak tersedia dan guru mengalami kesulitan dalam menerapkan materi pelajaran bermuatan kearifan lokal, sehingga siswa merasa jenuh dan bosan dalam belajar. Oleh karena itu, perlu adanya dukungan dari pemerintah setempat dalam perancangan kurikulum berkaitan tentang budaya kearifan lokal dalam pembelajaran di sekokah. Kearifan lokal sangat penting bagi guru untuk menerapkan kepada siswa karena pembelajaran berbasis kearifan lokal memberikan pengalaman langsung kepada siswa. Salah satu kearifan lokal yang ada di lingkungan siswa adalah kearifan lokal anyaman Nyiru. Anyaman Nyiru bisa digunakan sebagai salah satu media dalam pembelajaran di kelas. Untuk mendesain media pembelajaran berbasis kearifan lokal anyaman Nyiru perlu dilakukan beberapa tahap, yaitu melakukan tahap observasi, wawancara, serta dokumentasi. Observasi 
digunakan untuk melihat proses menganyam, wawancara digunakan untuk mengetahui informasi tentang proses menganyam, dan dokumentasi digunakan untuk mengambil gambar-gambar pada saat menganyam.

\section{Desain Produk}

Setelah mengumpulkan informasi tentang proses pembuatan anyaman Nyiru kemudian peneliti mendesain bahan ajar fisika berbasis kearifan lokal berdasarkan informasi yang sudah didapat. Berikut ini adalah hasil desain bahan ajar yang ditunjukkan pada Gambar 1. Gambar 1 menunjukkan desain bahan ajar berbasisi kearifan lokal anyaman Nyiru yang telah dikembangkan untuk digunakan dalam meningkatkan pemahaman konsep siswa pada materi Hukum Newton.

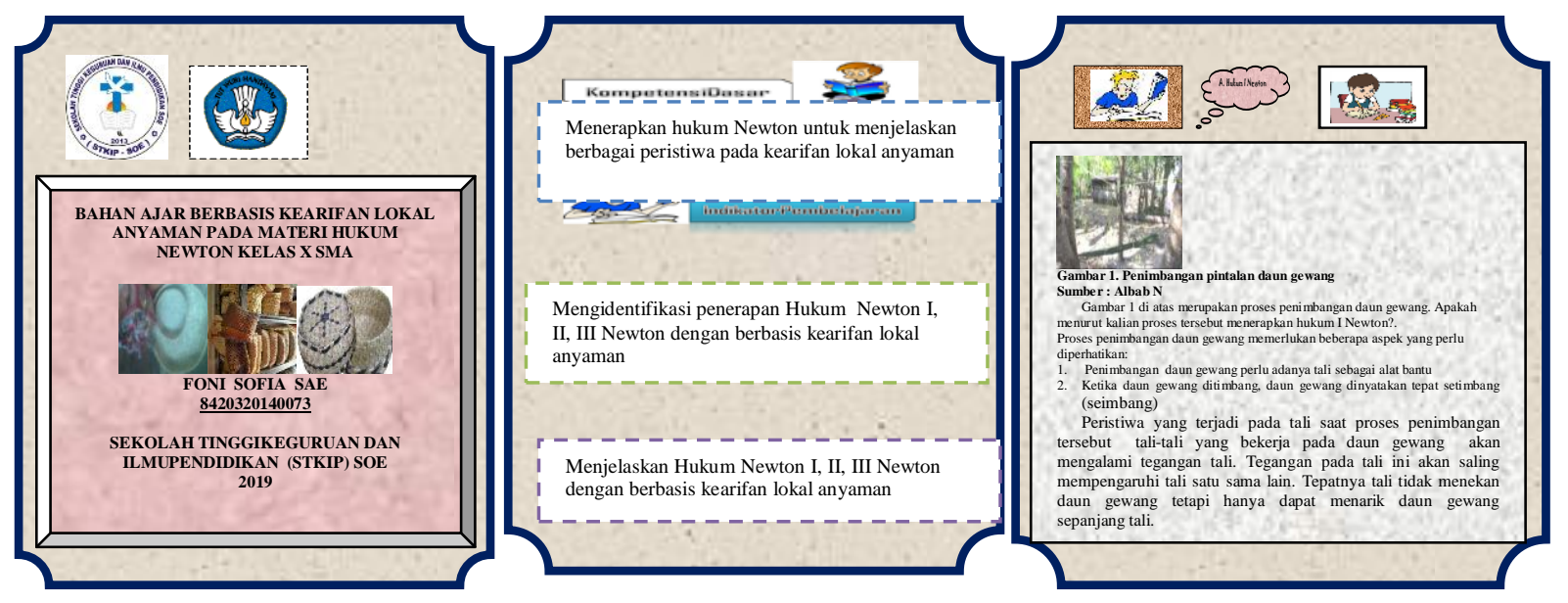

Gambar 1. Desain Bahan Ajar

\section{Validasi Desain}

Analisis Validasi untuk Ahli Materi

Sebelum melakukan penelitian terlebih dahulu dilakukan validasi terhadap bahan ajar yang telah dikembangkan. Berikut ini adalah hasil validasi untuk ahli materi yang ditunjukkan pada Gambar 2.

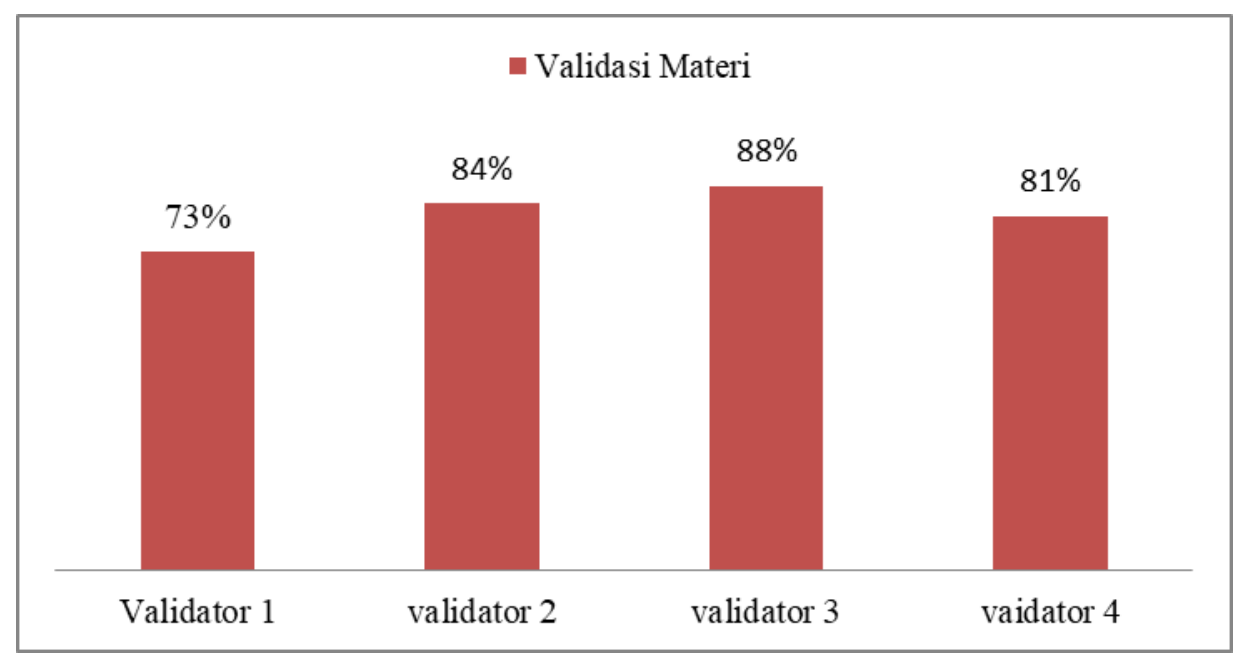

Gambar 2. Nilai Rata-Rata Validasi Materi

Gambar 2 menunjukkan hasil validasi untuk ahli materi yang terdiri dari 4 orang validator, diantaranya: 2 dosen fisika dan 2 guru fisika pada Sekolah Menengah Atas. Validator 1 memperoleh nilai rata-rata sebesar $73 \%$ dengan kriteria (tinggi) dan perlu direvisi. Validator 2 memperoleh nilai rata-rata sebesar $84 \%$ dengan kriteria (tinggi) dan perlu direvisi. Validator 3 memperoleh nilai ratarata sebesar $88 \%$ dengan kriteria (tinggi) dan perlu direvisi. Validator 4 memperoleh nilai rata-rata sebesar $81 \%$ dengan kriteria (tinggi) dan perlu direvisi. Secara keseluruhan dari hasil 4 validator 
didapatkan presentasi kelayakan rata-rata $82 \%$ sehingga menurut ahli materi, bahan ajar fisika berbasis kearifan lokal yang dikembangkan dalam kategori sangat baik.

\section{Analisis Validasi untuk Ahli Media}

Berikut ini adalah nilai validasi untuk ahli desain yang ditunjukkan pada Gambar 3.

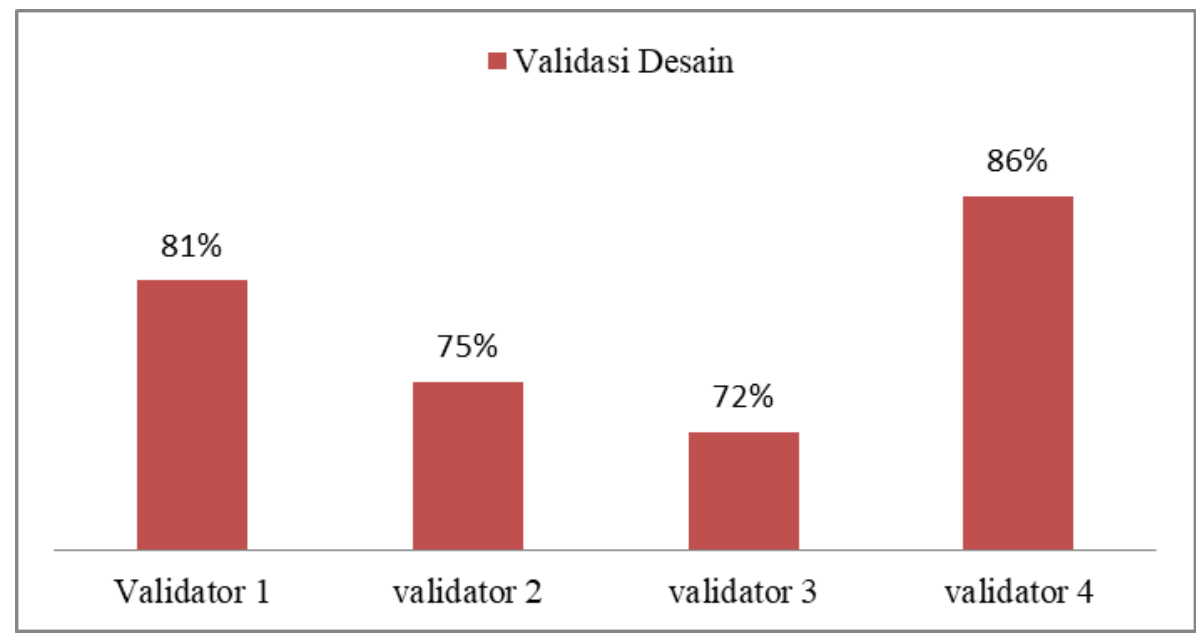

Gambar 3. Nilai Rata-Rata Validasi Desain

Gambar 3 menunjukkan hasil validasi untuk ahli media. Validator 1 memperoleh nilai rata-rata sebesar $81 \%$ dengan kriteria (tinggi). Validator 2 memperoleh nilai rata-rata sebesar $75 \%$ dengan kriteria (tinggi). Validator 3 memperoleh nilai rata-rata sebesar 72\% dengan kriteria (tinggi). Validator 4 memperoleh nilai rata-rata sebesar 86\% dengan kriteria (tinggi). Secara keseluruhan dari hasil 4 validator didapatkan presentasi kelayakan rata-rata 79\% sehingga menurut ahli media bahan ajar fisika berbasis kearifan lokal yang dikembangkan dalam kategori sangat baik.

\section{Revisi Produk}

Revisi produk dilakukan bertujuan untuk memperbaiki bahan ajar yang divalidasi oleh para validator berdasarkan masukan dan saran untuk mendapatkan produk yang memadai dan sesuai dengan kebutuhan di lapangan. Pada penelitian ini, selain mendapatkan data kuantitatif juga mendapatkan saran dan masukan dari ke-4 validator bahwa produk bahan ajar yang dikembangkan valid dan sangat baik dan perlu dilakukan revisi produk sebelum diujicobakan di sekolah.

\section{Uji Coba Produk (Skala Kecil)}

Setelah perbaikan desain dari validator maka bahan ajar perlu diujicobakan. Uji coba dilakukan di sekolah pada siswa kelas X SMA Kristen 1 SoE dan berjumlah 31 siswa dengan menggunakan bahan ajar berbasis kearifan lokal anyaman Nyiru yang sudah valid dan layak untuk digunakan dalam pembelajaran di kelas. Uji coba pada siswa kelas X diberikan soal tes berupa pilihan ganda sebanyak 15 butir soal. Uji $t$ dilakukan untuk mengetahui peningkatan nilai yang signifikan antara nilai pretest dan nilai posttest dimana harga $t_{\text {hitung }}(2,97)>t_{\text {tabel }}(1,69)$ dengan taraf signifikan 0,05 . Data tersebut menunjukkan bahwa nilai $t_{\text {hitung }}>t_{\text {tabel }}$, sehingga dapat disimpulkan bahwa terjadi peningkatan nilai pemahaman konsep yang signifikan pada nilai siswa saat menggunakan bahan ajar fisika berbasis kearifan lokal anyaman Nyiru dalam proses pembelajaran. Hasil pemahaman konsep siswa skor pretest, skor posttest, dan $\mathrm{N}$-Gain untuk setiap indikator ditunjukkan pada Tabel 1.

Tabel 1. Pemahaman Konsep Siswa dari Hasil Prestest dan Posttest

\begin{tabular}{cccc}
\hline $\begin{array}{c}\text { Nilai rerata } \\
\text { pretest }\end{array}$ & $\begin{array}{c}\text { Nilai rerata } \\
\text { posttest }\end{array}$ & N-Gain & Kategori \\
\hline 42,3 & 89,9 & 0,82 & Tinggi \\
\hline
\end{tabular}


Tabel 1 menunjukkan bahwa terdapat perbedaan hasil pemahaman konsep siswa pada kelas eksperimen sebelum dan sesudah pembelajaran menggunakan bahan ajar fisika berbasis kearifan lokal anyaman Nyiru dibandingkan dengan menggunakan pembelajaran konvensional. Terlihat bahwa skor rata-rata posttest 89,9 dengan kategori sangat tinggi dari nilai rata-rata pretest 42,3 . Hal ini menunjukkan bahwa adanya peningkatan pemahaman konsep fisika pada siswa SMA melalui pembelajaran yang menerapkan bahan ajar fisika berbasis kearifan lokal. Adanya peningkatan pemahaman konsep fisika pada siswa terlihat pada skor rata-rata $\mathrm{N}$-Gain pada setiap indikator sebesar 0,82 dengan kategori tinggi. Selaras dengan penelitian oleh Satriawan dan Rosmiati (2016) bahwa bahan ajar fisika kontekstual dengan mengintegrasikan kearifan lokal yang dikembangkan dapat meningkatan penguasaan konsep fisika siswa SMA pada materi Mekanika. Ibrahim (2014) menjelaskan bahwa mengintegrasikan kearifan lokal dalam aktifitas pendidikan dan pembelajaran sangat potensial untuk memunculkan suatu inovasi dengan kebaharuan dan kearifan lokal sebagai penginspirasi, yang memunculkan ide-ide baru di dalam pembelajaran.

Hasil analisis respon siswa terhadap bahan ajar berbasis kearifan lokal anyaman Nyiru diperoleh respon dari 31 siswa dengan keseluruhan persentase sebesar $74,86 \%$ dengan kategori baik. Hasil persentase ini menunjukkan bahwa bahan ajar berbasis kearifan lokal anyaman Nyiru valid dan dapat digunakan dalam kegiatan pembelajaran di kelas.

\section{KESIMPULAN}

Berdasarkan hasil penelitian dapat disimpulkan bahwa hasil validasi bahan ajar oleh 4 orang validator dengan rata-rata persentase media bahan ajar adalah $79 \%$ dengan kategori valid dan rata-rata persentase materi adalah $82 \%$ dengan kategori valid. Nilai N-gain terhadap pemahaman konsep siswa diperoleh nilai rata-rata sebesar 0,82 dengan kriteria tinggi dan data terhadap respon siswa diperoleh nilai rata-rata sebesar 74,86\% dengan kriteria Baik. Dengan demikian dapat disimpulkan bahwa bahan ajar berbasis kearifan lokal anyaman Nyiru yang dikembangkan layak untuk digunakan dalam pembelajaran serta dapat meningkatkan pemahaman konsep fisika siswa SMA pada materi Hukum Newton.

\section{DAFTAR PUSTAKA}

Albab, N.M. (2014). Pengembangan Modul Fisika Berbasis Kearifan lokal pada Materi Hukum Newton untuk siswa SMA N I Sentolo Kelas X Kulon Progo. Skripsi. Yogyakarta: Fakultas Sains dan Teknologi.

Bakhtiar. (2016). Bahan Ajar Berbasis Kearifan Lokal Terintegrasi STM (Sains, Teknologi Dan Masyarakat) Pada Mata Pelajaran Fisika. Prosiding Seminar Nasional Pendidikan. Universitas Jamber.

Borg, W.R. \& Gall, M.D. (1989). Educational Research An Introduction. New York: Longman.

Husin, V., Wiyanto., \& Teguh, D. (2018). Integritas Kearifan Lokal Rumah Umekbubu dalam Bahan Ajar Materi Suhu dan Kalor untuk meningkatkan Motivasi dan Hasil Belajar Siswa SMA. Physics Communication, 2(1), 26-35.

Ibrahim, M. (2014). Inovasi Pembelajaran Sains Berbasis Kearifan Lokal. Dalam Makalah Utama Seminar Nasional "Sains dan Inovasi Pembelajaran Berbasis Kearifan Lokal", 22 November 2014, IKIP Mataram.

Kuswandari, M., Sunarno, W., \& Supurwoko (2013). Pengembangan Bahan Ajar Fisika SMADengan Pendekatan Pada Materi Pengukuran Besaran Fisika. Jurnal Pendidikan Fisika, 1, 41. Surakarta: Fakultas Keguruan danIlmu Pendidikan Universitas Sebelas Maret Surakarta, Indonesia. (ISSN: $2338-069$ ).

Nurrahmi, R. (2018). Pengembangan Modul Berbasis Kearifan Lokal Daerah Istimewa Yogyakarta UntukSiswa Kelas III Sekolah Dasar. Jurnal Pendidikan Guru Sekolah Dasar. Fakultas Ilmu Pendidikan, Universitas Negeri Yogyakarta. 
Oktaviani, W. Gunawan, \& Sutrio. (2017). Pengembangan Bahan Ajar Fisika Kontekstual Untuk Meningkatkan Penguasaan Konsep Siswa. Jurnal Pendidikan Fisika dan Teknologi, 3(1). Program Studi Pendidikan Fisika FKIP Universitas Mataram. (ISSN. 2407-6902).

Rahayu, A., Sutikno., \& Masturi. (2015). Pengembangan Media Pembelajaran Hukum Newton Menggunakan Fotonovela Berbasis Kearifan Lokal. Prosiding Seminar Nasional Fisika, 4, 33-37. p-ISSN: 2339-0654.

Sanjaya, Wina. (2009). Strategi Pembelajaran Berorientasi Standar Proses Pendidikan. Jakarata: Kencana Prenada Media Group.

Satriawan, M., \& Rosmiati. (2016). Pengembangan Bahan Ajar Fisika Kontekstual dengan Mengintegrasikan Kearifan Lokal untuk Meningkatkan Pemahaman Konsep pada Mahasiswa. Jurnal Pendidikan Sains Pascasarjana Universitas Negeri Surabaya, 6. (ISSN: 2089-1776).

Sundayana, H.R. (2015). Statistika Penelitian Pendidikan. Bandung: Alfabeta.

Tanjung, A., \& Fahmi, M. (2015). Urgensi Pengembangan Bahan Ajar Geografi Berbasis Kearifan Lokal. Jurnal Pendidikan Geografi, 20(1).

Trianto. (2011). Model Pembelajaran Terpadu Konsep,Strategi dan Implementasinya dalam Kurikulum Tingkat Satuan Pendidikan (KTSP). Jakarta: Bumi Aksara. 